\title{
Tiotropium bromide inhibits TGF- $\beta$-induced MMP production from lung fibroblasts by interfering with Smad and MAPK pathways in vitro
}

This article was published in the following Dove Press journal: International Journal of Chronic Obstructive Pulmonary Disease 28 August 2010

Number of times this article has been viewed

\author{
Kazuhito Asano' \\ Yusuke Shikama ${ }^{2}$ \\ Naruo Shoji ${ }^{3}$ \\ Kojiro Hirano ${ }^{3}$ \\ Harumi Suzaki ${ }^{3}$ \\ Hiroaki Nakajima ${ }^{2}$ \\ 'Division of Physiology, School of \\ Nursing and Rehabilitation Sciences, \\ Showa University, Yokohama, \\ Japan; ${ }^{2}$ Department of Respiratory \\ Diseases, Showa University Northern \\ Yokohamashi Hospital, Yokohama, Japan; \\ ${ }^{3}$ Department of Otorhinolaryngology, \\ School of Medicine, Showa University, \\ Tokyo, Japan
}

Background: Chronic obstructive pulmonary disease (COPD) is characterized by chronic inflammation and structural alterations (ie, tissue remodeling) throughout the conducting airways, parenchyma, and pulmonary vasculature. Matrix metalloproteinases (MMPs) are extracellular degrading enzymes that play a critical role in inflammatory cell infiltration and tissue remodeling, but the influence of the agents that are used for the treatment of COPD on the production of MMPs is not well understood.

Purpose: The present study aimed to examine the influence of tiotropium bromide hydrate (TBH) on the production of MMPs from lung fibroblasts (LFs) induced by transforming growth factor (TGF)- $\beta$ in vitro.

Methods: LFs, at a concentration of $5 \times 10^{5}$ cells $\cdot \mathrm{mL}^{-1}$, were stimulated with TGF- $\beta$ in the presence of various concentrations of TBH. MMP-1 and MMP-2 levels in culture supernatants were examined by enzyme-linked immunosorbent assay (ELISA), and MMP messenger ribonucleic acid (mRNA) expression was examined by real-time polymerase chain reaction (RT-PCR). The influence of TBH on TGF- $\beta$ signaling pathways was also analyzed by examining Smad activation and signaling protein phosphorylation by ELISA.

Results: TBH at more than $15 \mathrm{pg} \cdot \mathrm{mL}^{-1}$ inhibited the production of MMP-1 and MMP-2, but not tissue inhibitor of matrix metalloproteinase (TIMP)- 1 and TIMP-2, from LFs, after TGF- $\beta$ stimulation. TBH also suppressed MMP mRNA expression through the inhibition of Smad activation and signaling protein, extracellular-signal-regulated kinase (ERK) 1 and 2, and c-Jun N-terminal kinase (JNK), phosphorylation.

Conclusion: These results may suggest that TBH suppresses MMP production from LFs, through interference of TGF- $\beta$-mediated signaling pathways and results in favorable modification of the clinical status of COPD.

Keywords: tiotropium bromide, matrix metalloproteinases, lung fibroblast, TGF- $\beta$, inhibition, in vitro

\section{Introduction}

Chronic obstructive pulmonary disease (COPD) is well accepted to be a major public health problem, associated with long-term exposure to toxic gases and particles and most often related to cigarette smoking. ${ }^{1,2}$ Histological observations of both biopsy specimens of patients with COPD show structural abnormalities such as increased smooth muscle mass; subepithelial fibrosis; and thickening of airway walls, with the intense infiltration of inflammatory cells, including macrophages and neutrophils., ${ }^{3,4}$ These cellular events are now called tissue remodeling and involve extensive alteration of extracellular matrix (ECM), which is essential for supporting normal lung functions. ${ }^{5}$
Correspondence: Kazuhito Asano

Division of Physiology, School of

Nursing and Rehabilitation Sciences,

Showa University, Midori-ku,

Yokohama, 226-8555, Japan

Tel +8I 459857583

Fax +81459856538

Email asanok@med.showa-u.ac.jp 
Matrix metalloproteinases (MMPs) are a family of $\mathrm{Ca}^{2+}$-activated, $\mathrm{Zn}^{2+}$-dependent proteases, which are secreted by a wide variety of various cells (eg, inflammatory cells and fibroblasts). MMPs are also accepted to be broadly classified on the basis of substrate specificity into: collagenase (MMP-1 and MMP-8); gelatinase (MMP-2 and MMP-9); and elastase (MMP-7 and MMP-12), among others ${ }^{5,6}$ and can degrade one or several constituents of ECM. In normal physiological conditions, MMPs promote remodeling of ECM, thus facilitating cell migration, and are implicated in the development of immune responses by cleaving the inactive forms of cytokines and chemokines..$^{5}$ On the other hand, in pathological conditions, a switch in MMP production and activity occurs, which leads to excessive lung inflammation and abnormal tissue destruction. ${ }^{7}$ There is increasing evidence for a role of MMPs in COPD. In patients with emphysema, which is the most important histological finding of COPD, there is an increase in both bronchoalveolar lavage (BAL) fluid concentration and lung tissue expression of MMP-1 and MMP-9, and these are correlated with a decrease in forced expiratory volume in one second $\left(\mathrm{FEV}_{1}\right){ }^{8,9}$ It is also observed that desmosine, a degradation product of elastic fiber, which is one of the important components of ECM for lungs, is increased in the urine of subjects with $\mathrm{COPD}^{10}$ and correlates with the rate of lung function decline. ${ }^{11}$ Furthermore, MMP-2 expression in lung periphery progressively increases as lung function worsens and degree of emphysema increases. ${ }^{8}$ These reports may suggest that MMPs, including MMP-1, MMP-2, and MMP-9, play essential roles in the development of COPD, however very few studies have examined the influence of agents that are used for the treatment of COPD on MMP. ${ }^{12}$

The transforming growth factor (TGF)- $\beta$ subfamily is critically involved in embryonic development (organogenesis) and act as multifunctional regulators of cell growth and differentiation. ${ }^{13,14}$ Several studies have reported an increased expression of TGF- $\beta$ in the airway epithelium of COPD patients. ${ }^{15-17}$ It is also reported that increased TGF- $\beta$, as well as TGF- $\beta$ receptor, expression in the bronchiolar and alveolar epithelium of COPD patients is correlated with clinical future, such as lung function and histological changes of COPD,${ }^{17}$ suggesting an impact of TGF- $\beta$ signaling on the development and progression of COPD. Furthermore, there is much evidence that fibrotic alterations are crucial in airway remodeling in COPD and anti-obstructive agents such as muscarinic antagonists and $\beta$-adrenoceptor agonists appear to delay the decline in lung function through the inhibition of fibroblast functions, including proliferation and collagen synthesis. ${ }^{18,19}$
Tiotropium bromide hydrate (TBH), the first choice agent in the treatment of COPD, ${ }^{20}$ is a once-daily inhaled anticholinergic bronchodilator, which binds to muscarinic receptor subtypes, especially $\mathrm{M}_{3}{ }^{20}$ There is much evidence showing that administration of TBH in COPD patients could prevent airway smooth muscle remodeling. ${ }^{21,22}$ Although these reports may suggest that TBH exerts a suppressive effect on MMP production, or inhibition of MMP activation in airways, there is little evidence showing the influence of TBH on MMPs. ${ }^{12}$ In the present study, therefore, we examined the influence of TBH on the production of MMP-1, MMP-2, and MMP-9, from human lung fibroblasts (LFs), after TGF- $\beta$ stimulation in vitro.

\section{Materials and methods \\ Agent}

TBH was kindly donated by Nippon Boehringer Ingelhein Co. Ltd. (Tokyo, Japan), as a preservative-free pure powder. The powder was dissolved in a Roswell Park Memorial Institute medium (RPMI-1640), supplemented with $10 \%$ fetal bovine serum (RPMI-FCS) at a concentration of $10 \mu \mathrm{g} \cdot \mathrm{mL}^{-1}$. This solution was then sterilized by passing through $0.2 \mu \mathrm{m}$ filters and stored at $4^{\circ} \mathrm{C}$ as stock solution until used. All dilutions used in this study were prepared from this stock solution, by diluting with RPMI-FCS. Recombinant TGF- $\beta$ (preservative-free) was purchased from R\&D Systems Inc. (Temecula, CA, USA) and diluted with RPMI-FCS to give a concentration of $50 \mathrm{ng} \cdot \mathrm{mL}^{-1}$.

\section{Cell source and induction of fibroblasts}

Tissue samples from patients without lung fibrosis or COPD were obtained from healthy tissue area, during pneumonectomy for tumor resection from a tumor-free area. All donors ( 3 female: $43-71$ years; 2 male: 41 and 71 years) provided written informed consent, which was approved by the Ethics Committee of Showa University. The cells were induced from diced tissue specimens (approximately $1 \mathrm{~mm}^{2}$ ) according to the method described previously. ${ }^{12}$ The cells were then characterized, ${ }^{23}$ and those with fibroblast purity of more than $99 \%$ used as LFs. LFs at five to six passages were used for the following experiments.

\section{Cell culture}

LFs were washed several times with RPMI-FCS and introduced into each well of 24-well culture plates in triplicate, at a concentration of $5 \times 10^{5}$ cells $\cdot \mathrm{mL}^{-1}$ in a volume of $1 \mathrm{~mL}$. The cells were stimulated with $2.5 \mathrm{ng} \cdot \mathrm{mL}^{-1} \mathrm{TGF}-\beta$, in the presence of various concentrations of TBH, in a final volume 
of $2 \mathrm{~mL}$. After $24 \mathrm{~h}$, the culture supernatants were removed and stored at $-40^{\circ} \mathrm{C}$ until used. ${ }^{12}$ To examine transcription factor activation and messenger ribonucleic acid (mRNA) expression, LFs were cultured in a similar manner for $4 \mathrm{~h}$ and stored at $-80^{\circ} \mathrm{C}$ until used. ${ }^{12}$ In preparing cells to examine signaling protein phosphorylation, LFs were cultured in a similar manner, in 96-well flat-bottomed culture plates for 30 min. ${ }^{24}$ In all cases, TBH was added to cell cultures $2 \mathrm{~h}$ before the stimulation with TGF- $\beta$.

\section{Assay for MMP and tissue inhibitor of matrix metalloproteinase (TIMP)}

MMP-1, MMP-2, MMP-9, TIMP-1, and TIMP-2 levels in culture supernatants were assayed using commercially available human MMP and TIMP enzyme-linked immunosorbent assay (ELISA) test kits (Amersham Biosciences, Bucks, UK), according to the manufacturer's recommendations. The results are expressed as the mean $\left(\mathrm{ng} \cdot \mathrm{mL}^{-1}\right) \pm$ standard error (SE) of duplicate assays for five different subjects. According to the manufacturer's data sheet, the ELISA kits used are specific for the corresponding enzymes and completely recognized free prometalloproteinase (proMMP) and that complexed with TIMP, but not the active form of MMP. The minimum detectable levels of these ELISA kits were $1.7 \mathrm{ng} \cdot \mathrm{mL}^{-1}$ for MMP-1; $0.37 \mathrm{ng} \cdot \mathrm{mL}^{-1}$ for MMP-2; $0.6 \mathrm{ng} \cdot \mathrm{mL}^{-1}$ for MMP-9; $40 \mathrm{ng} \cdot \mathrm{mL}^{-1}$ for TIMP-1; and $3.0 \mathrm{ng} \cdot \mathrm{mL}^{-1}$ for TIMP-2. The activities of MMP-1, MMP-2, and MMP-9 were also examined with commercially available human MMP activity ELISA test kits, according to the manufacturer's recommendations. The manufacturer's data sheets showed that these ELISA kits recognized free proMMPs (MMP-2 and MMP-9), and that the minimum detectable levels of these kits were $0.5 \mathrm{ng} \cdot \mathrm{mL}^{-1}$ for MMP-1; $2.0 \mathrm{ng} \cdot \mathrm{mL}^{-1}$ for MMP-2; and $0.5 \mathrm{ng} \cdot \mathrm{mL}^{-1}$ for MMP-9.

\section{Real-time polymerase chain reaction (PCR)}

mRNA was extracted from fibroblasts using magnetic-activated cell sorting (MACS) mRNA isolation kits (Miltenyi Biotec GmbH, Bergisch Gladbach, Germany), according to the manufacturer's instructions. The first-strand complementary deoxyribonucleic acid (cDNA) synthesis from 1.0 $\mu \mathrm{g}$ mRNA was performed using the SuperScript Preamplification System for cDNA synthesis (GIBCO BRL, Gaithersburg, MD, USA). PCR was then carried out using a GeneAmp ${ }^{\circledR} 5700$ Sequence Detection System (Applied Biosystems, Foster City, CA, USA). PCR mixture consisted of $2.0 \mu \mathrm{L}$ of sample cDNA solution (10.0 ng. $\left.\mu \mathrm{L}^{-1}\right) ; 25.0 \mu \mathrm{L}$ of SYBR ${ }^{\circledR}$ Green Master Mix (Life Technologies Corporation, Carlsbad, CA, USA); $0.3 \mu \mathrm{L}$ of both sense and antisense primers; and distilled water, to give a final volume of $50 \mu \mathrm{L}$. The reaction was conducted as follows: $4 \mathrm{~min}$ at $95^{\circ} \mathrm{C}$, followed by 40 cycles of $15 \mathrm{sec}$ at $95^{\circ} \mathrm{C}$, and $60 \mathrm{sec}$ at $60^{\circ} \mathrm{C}$. $\beta$-actin was amplified as an internal control. mRNA levels were calculated by using the comparative parameter threshold cycle $(\mathrm{Ct})$ and normalized to $\beta$-actin. Oligonucleotide sequences of the primers used are shown in Table 1.

\section{Assay for Smad-2 and Smad-4 activities}

Smad-2 activity was analyzed with commercially available ELISA test kits (Active Motif, Carlsbad, CA, USA) that contained sufficient reagents, biotin-labeled double strand oligonucleotides with consensus sequence for Smad-2 (probe), and primary and secondary antibodies, according to the manu-

Table I Primer sequences used for real-time polymerase chain reaction

\begin{tabular}{lcc}
\hline Primer sequences & Position & Product size (bp) \\
\hline MMP-I & \\
Sense 5'-GTTCCCAAAATCCTGTCC-3' & $741-766$ & 261 \\
Antisense 5'-CGTGTAGCGCATTCTGTCC-3' & $962-943$ \\
MMP-2 & \\
Sense 5'-AGATCTTCTTCTTCAAGGACCGGTT233' & $1740-1764$ \\
Antisense 5'-GGCTGGTCAGTGGCTTGGGGTA-3' & $1964-1943$ \\
TIMP-I & \\
Sense 5'-CACCCACAGACGGCCTTATGCAAT-3' & $150-173$ \\
Antisense 5'-AGTGTAGGTCTTGGTGAAGCC-3' & $494-474$ \\
TIMP-2 & \\
Sense 5'-CTCGCTGGACGTTGGAGGAAAGAA-3' & $602-625$ \\
Antisense 5'-AGCCCATCTGGTACCTGTGGTTCA-3' & 345 \\
B-actin & $756-733$ \\
Sense 5'-ACCCACACTGTGCCCATCTA-3' & \\
Antisense 5'-CGGAACCGCTCATTGCC-3' & $551-570$ \\
\hline
\end{tabular}


facturer's recommended procedure. In brief, nuclear extract $\left(2.0 \mu \mathrm{g} . \mu \mathrm{L}^{-1}\right.$ protein) from LFs was introduced into each well of 96-well microtiter plates, that contained $2.5 \mu \mathrm{L}$ probe and $10.0 \mu \mathrm{L}$ double strand oligonucleotide corresponding with probe, in a volume of $80 \mu \mathrm{L}$. These were then incubated for $30 \mathrm{~min}$ at $25^{\circ} \mathrm{C}$. After washing three times, $45 \mu \mathrm{L}$ samples were added to the appropriate wells of a 96-well plate coated with streptavidin and incubated for a further $1 \mathrm{~h}$ at $25^{\circ} \mathrm{C}$. Primary antibody against Smad-2 protein in a volume of $50 \mu \mathrm{L}$ was then added and incubated for $1 \mathrm{~h}$ at $25^{\circ} \mathrm{C}$. After washing the plate, anti-immunoglobulin $\mathrm{G}$ horseradish peroxidase (anti-IgG HRP-conjugate) in a volume of $100 \mu \mathrm{L}$ was then added and incubated for a further $1 \mathrm{~h}$ at $25^{\circ} \mathrm{C}$. After addition of tetramethylbenzine solution, absorbance at $450 \mathrm{~nm}$ was measured with the ELISA plate reader. Smad-4 activity was also examined, using a commercially available ELISA test kit (Active Motif, Carlsbad, CA, USA) in a similar manner.

\section{Assay for signaling protein phosphorylation}

Phosphorylation of signaling proteins, extracellular-signalregulated kinase (ERK) 1 and 2; p38 mitogen-activated protein kinases (p38 MAPK); and c-Jun N-terminal kinase (JNK), was analyzed with commercially available ELISA test kits (Active Motif, Carlsbad, CA, USA), according to the manufacturer's recommendations. In brief, LFs stimulated with $2.5 \mathrm{ng} \cdot \mathrm{mL}^{-1}$ TGF- $\beta$ were fixed with $4 \%$ formaldehyde for $20 \mathrm{~min}$ at $25^{\circ} \mathrm{C}$. After washing the plate, the primary antibody against phosphorylated-ERK1/2, p38 MAPK, or JNK was added into each well in a volume of $40 \mu \mathrm{L}$ and incubated for $12 \mathrm{~h}$ at $4^{\circ} \mathrm{C}$. After removing the antibody by washing the plate, $100 \mu \mathrm{L}$ of HRP-conjugated secondary antibody was added. After $1 \mathrm{~h}$ at $25^{\circ} \mathrm{C}$, tetramethylbenzine solution was added in a volume of $100 \mu \mathrm{L}$ per well and absorbance at $450 \mathrm{~nm}$ was measured followed by addition of $2 \mathrm{~N}$ Hydrogen Chloride $(2 \mathrm{~N} \mathrm{HCl})$.

\section{Statistical analysis}

The statistical significance of the difference between the control and experimental data was analyzed using ANOVA followed by Fisher's protected least significant difference (PLSD) test. A $P$ value $<0.05$ was accepted as statistically significant.

\section{Results}

\section{Influence of TGF- $\beta$ stimulation on MMP production from LFs}

The first experiments were undertaken to examine the optimal dose of TGF- $\beta$ on MMP production from LFs in vitro. LFs $\left(5 \times 10^{5}\right.$ cells $\left.\cdot \mathrm{mL}^{-1}\right)$ were stimulated with various concentrations of TGF- $\beta$ for $24 \mathrm{~h}$. MMP-2 and MMP-9 levels in culture supernatants were examined by ELISA. Data are expressed as the mean $\left(\mathrm{pg} \cdot \mathrm{mL}^{-1}\right) \pm$ standard error (SE), for five different subjects.

As shown in Figure 1, stimulation of LFs with $1.0 \mathrm{ng} \cdot \mathrm{mL}^{-1}$ TGF- $\beta$ significantly increases MMP-2 levels in culture supernatants, as compared with non-stimulated control. The ability of LFs to produce MMP-2 was further increased when $2.5 \mathrm{ng} \cdot \mathrm{mL}^{-1} \mathrm{TGF}-\beta$ was used for stimulation, and culture supernatants contained much higher levels of MMP-2 than that in supernatants stimulated with $1.0 \mathrm{ng} \cdot \mathrm{mL}^{-1} \mathrm{TGF}-\beta$ (Figure 1). However, TGF- $\beta$ stimulation exerts a suppressive effect on MMP-2 production when the agent at $5.0 \mathrm{ng} \cdot \mathrm{mL}^{-1}$ or more was used for stimulation (Figure 1). On the other hand, TGF- $\beta$ stimulation could not induce MMP-9 production from LFs: culture supernatants contained undetectable levels of MMP-9 $\left(<0.5 \mathrm{ng} \cdot \mathrm{mL}^{-1}\right)$ by ELISA (data not shown).

\section{Influence of TBH on MMP-I, MMP-2, TIMP-I and TIMP-2 production from LFs}

The second set of experiments was undertaken to examine the influence of TBH on MMPs production from LFs in response to TGF- $\beta$ stimulation. LFs $\left(5 \times 10^{5}\right.$ cells $\left.\cdot \mathrm{mL}^{-1}\right)$ were stimulated with $2.5 \mathrm{ng} \cdot \mathrm{mL}^{-1} \mathrm{TGF}-\beta$ in the presence of $0,5.0,7.5,10.0,15.0,20.0$, 25.0, or 30.0 pg.mL $\mathrm{mL}^{-1} \mathrm{TBH}$ for $24 \mathrm{~h}$. MMP-1 and MMP-2 levels in culture supernatants were assayed by ELISA. Data are expressed as the mean ng. $\mathrm{mL}^{-1} \pm \mathrm{SE}$, for five different subjects. As shown in Figure 2A, treatment of LFs with TBH at more than $15.0 \mathrm{ng} \cdot \mathrm{mL}^{-1}$

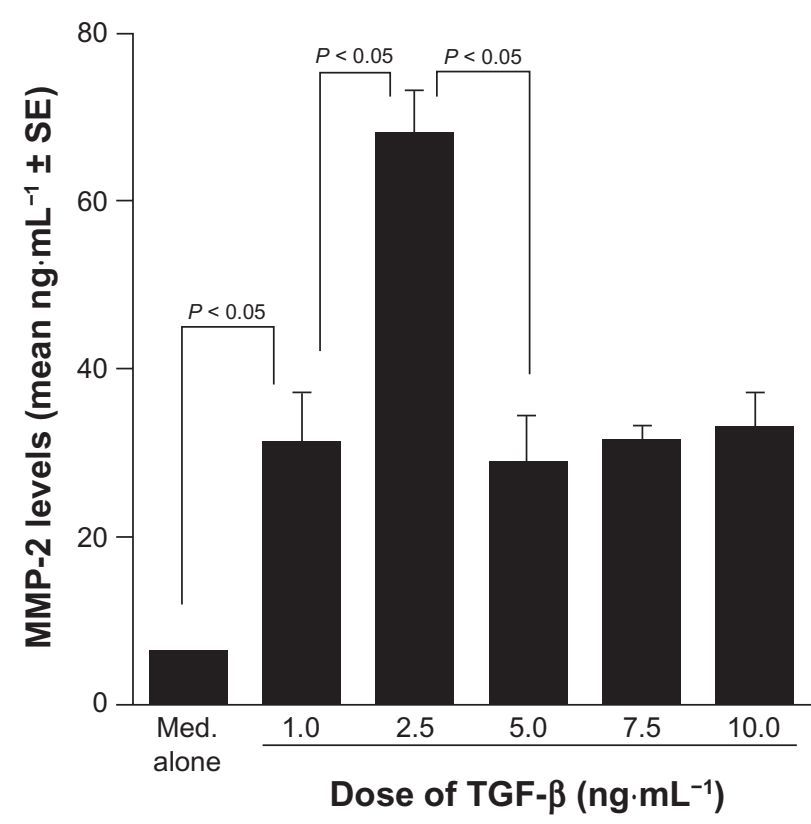

Figure I Influence of TGF- $\beta$ stimulation on MMP-2 production from lung fibroblasts in vitro. 
A

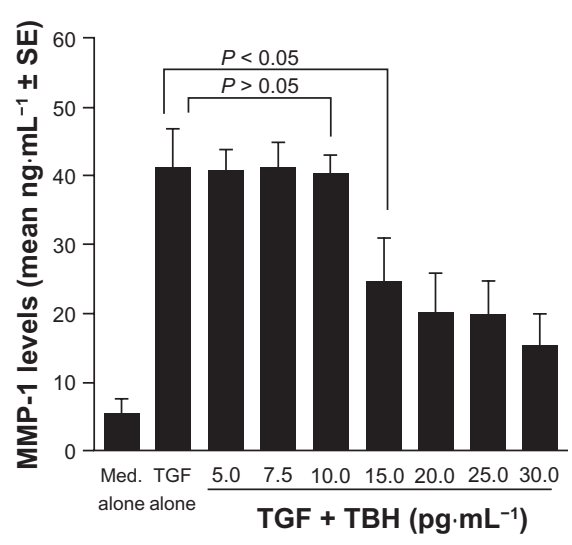

C

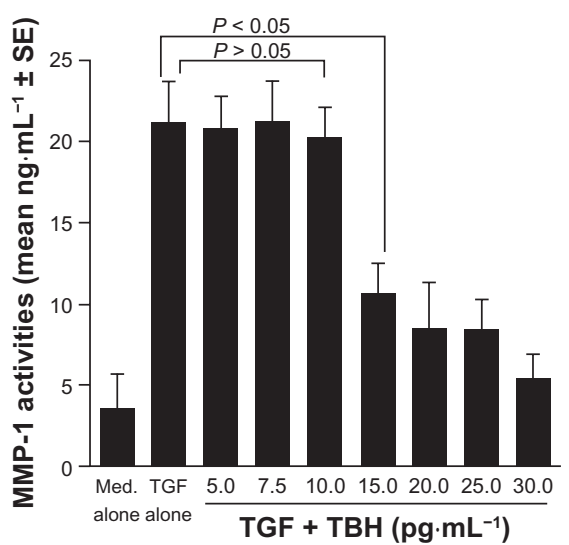

B

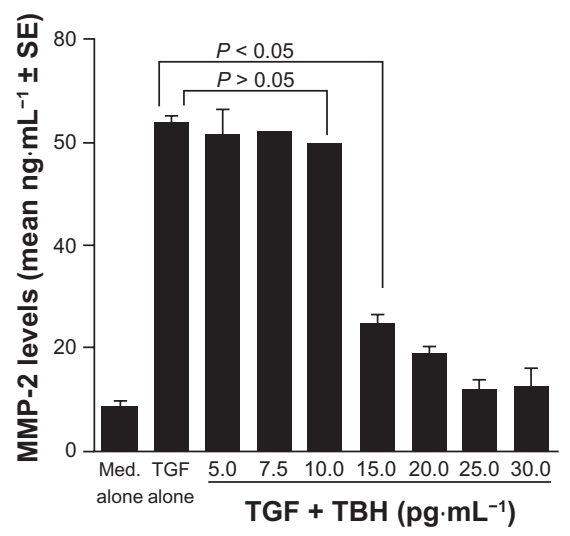

D

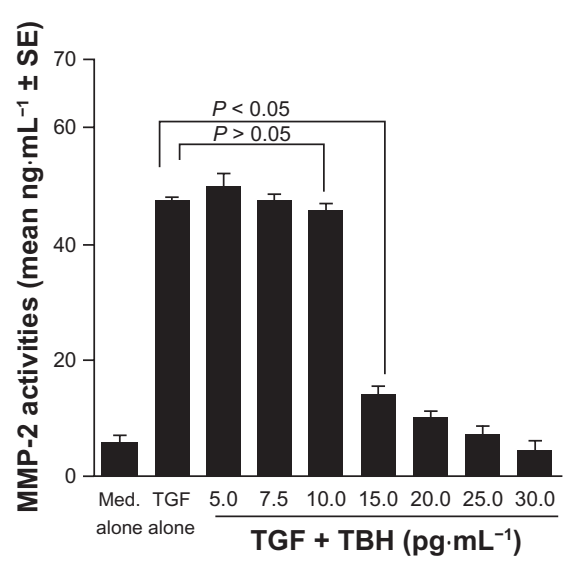

Figure 2 Suppressive activity of tiotropium bromide hydrate (TBH) on the production of MMP-I and MMP-2 by TGF- $\beta$ stimulation from lung fibroblasts and on their activities.

caused significant suppression of MMP-1 production from cells, which was increased by TGF- $\beta$ stimulation. TBH also suppressed TGF- $\beta$-induced MMP-2 production from LFs (Figure $2 \mathrm{~B}$ ). The minimum concentration of the agent which caused significant suppression of MMP-2 production was $15.0 \mathrm{pg} \cdot \mathrm{mL}^{-1}$ (Figure $2 \mathrm{~B}$ ). We next examined the influence of TBH on the enzymatic activities of MMP-1 and MMP-2. The data in Figures 2C and 2D clearly show that addition of TBH into cell cultures at more than 15.0 $\mathrm{pg} \cdot \mathrm{mL}^{-1}$ could significantly suppress the activity of both MMP-1 and MMP-2 in culture supernatants. The final experiments in this section were undertaken to examine the production of both TIMP-1 and TIMP-2 from LFs in response to TGF- $\beta$ stimulation. As shown in Figure 3, TBH could not suppress the ability of LFs to produce TIMP-1 and TIMP-2 from LFs, even when $30.0 \mathrm{pg} \cdot \mathrm{mL}^{-1}$ of the agent was added to cell cultures.

\section{Influence of TBH on MMP and TIMP mRNA expression in LFs}

The third set of experiments was undertaken to examine the influence of TBH on mRNA expression for MMP-1, MMP-2, TIMP-1, and TIMP-2 in LFs. LFs $\left(5 \times 10^{5}\right.$ cells $\left.\cdot \mathrm{mL}^{-1}\right)$ were stimulated with $2.5 \mathrm{ng} \cdot \mathrm{mL}^{-1}$ TGF- $\beta$ in the presence of $0,5.0$, 15.0, 20.0, or $25.0 \mathrm{pg} \cdot \mathrm{mL}^{-1} \mathrm{TBH}$ for $4 \mathrm{~h}$. Levels of mRNA expression were evaluated by real-time PCR. Data are expressed as the mean $\% \pm \mathrm{SE}$, for five different subjects. Addition of $\mathrm{TBH}$ at more than $15.0 \mathrm{pg} \cdot \mathrm{mL}^{-1}$ into cell cultures significantly suppressed mRNA expression for MMP-1 and MMP-2 in LFs (Figure 4). However, TBH could not reduce levels of TIMP-1 and TIMP-2 mRNA expression in LFs (Figure 4).

\section{Influence of TBH on transcription factor activation in LFs}

The fourth set of experiments was designed to examine the influence of TBH on transcription factor (Smad-2 and Smad-4) activation in LFs. LFs $\left(5 \times 10^{5}\right.$ cells $\left.\cdot \mathrm{mL}^{-1}\right)$ were stimulated with $2.5 \mathrm{ng} \cdot \mathrm{mL}^{-1} \mathrm{TGF}-\beta$ in the presence of 0,5 , $10,15,20$, or $25 \mathrm{pg} \cdot \mathrm{mL}^{-1} \mathrm{TBH}$ for $4 \mathrm{~h}$. The nuclear extract was prepared and Smad activity was assessed by ELISA. Data are expressed as the mean OD at $450 \mathrm{~nm} \pm \mathrm{SE}$, for five different subjects. As shown in Figure 5, addition of TBH at more than $15 \mathrm{pg} \cdot \mathrm{mL}^{-1}$ caused significant suppression of Smad activation in LFs, which was induced by TGF- $\beta$ stimulation. 

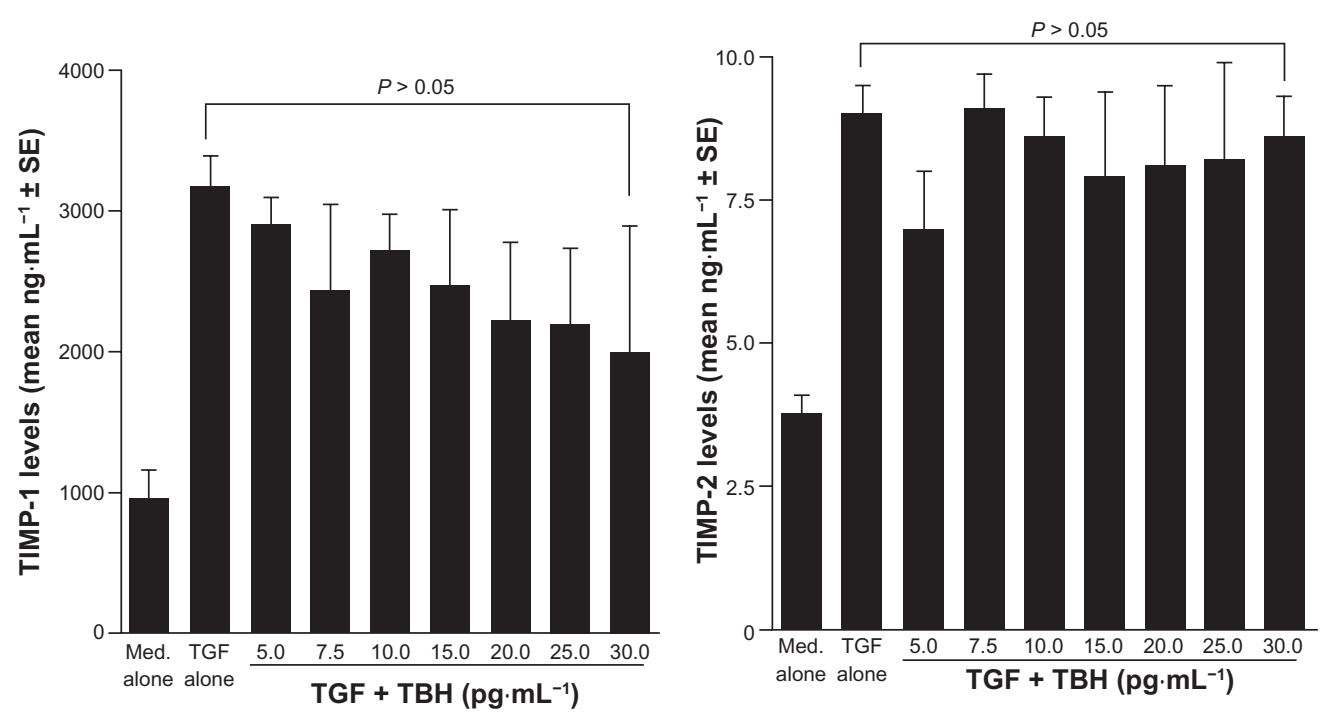

Figure 3 Influence of tiotropium bromide hydrate (TBH) on TIMP production by TGF- $\beta$ stimulation from lung fibroblasts.

\section{Influence of TBH on the phosphorylation of signaling proteins}

The final set of experiments was undertaken to examine the influence of TBH on signaling protein phosphorylation after TGF- $\beta$ stimulation in LFs. To do this, LFs were stimulated with $2.5 \mathrm{ng} \cdot \mathrm{mL}^{-1} \mathrm{TGF}-\beta$, in the presence of $5,15,20$, and $25 \mathrm{pg} \cdot \mathrm{mL}^{-1} \mathrm{TBH}$ for $30 \mathrm{~min}$, and phosphorylation of $\mathrm{p} 38$ MAPK, JNK, and ERK1/2 were examined by ELISA. Data are expressed as the mean $\mathrm{OD}$ at $450 \mathrm{~nm} \pm \mathrm{SE}$, for five different subjects. Treatment of LFs with TBH could not
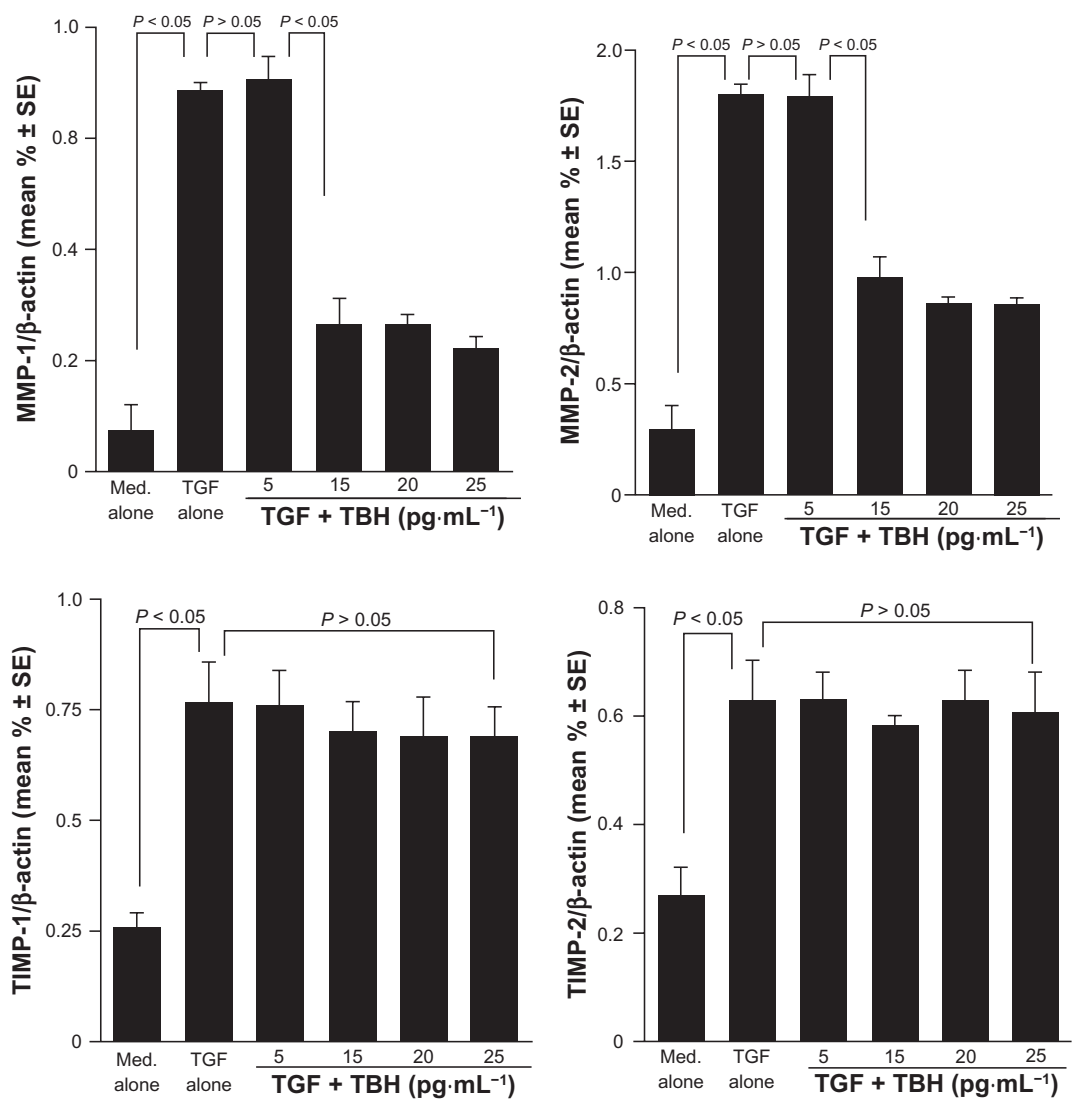

Figure 4 Influence of tiotropium bromide hydrate (TBH) on mRNA expression for MMP-I, MMP-2, and TIMPs in lung fibroblasts after TGF- $\beta$ stimulation. 

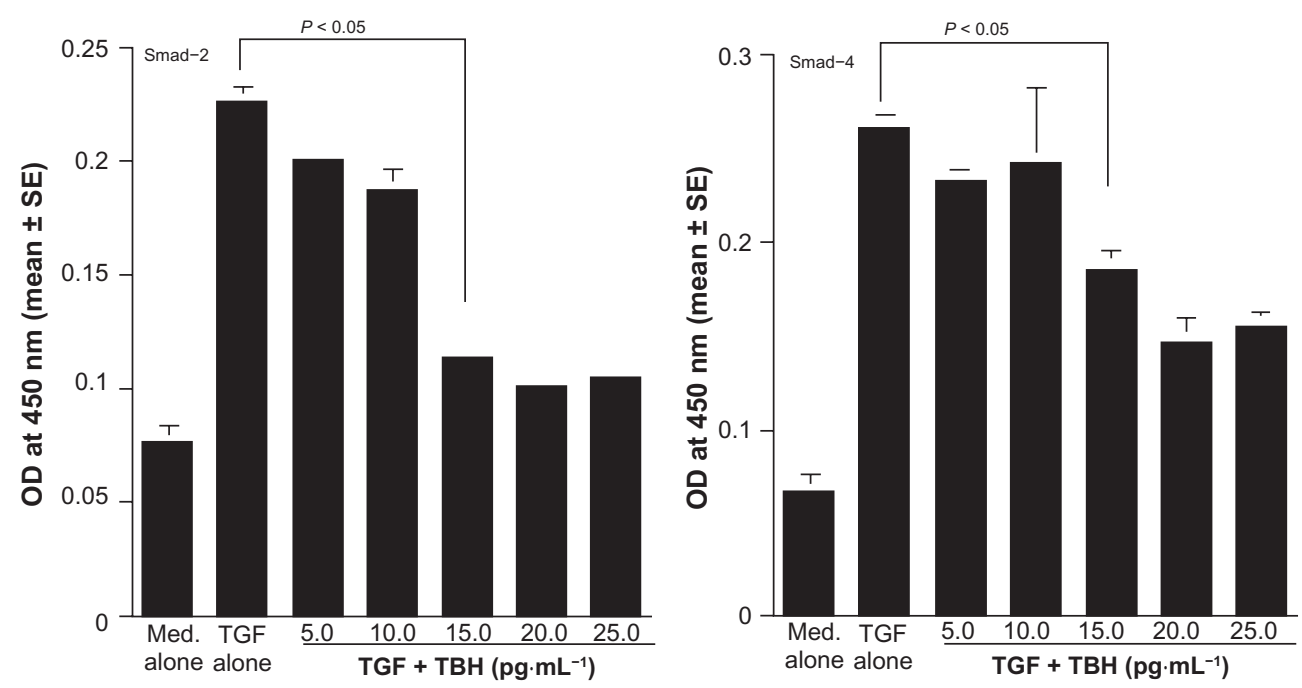

Figure 5 Influence of tiotropium bromide hydrate (TBH) on Smad activation by TGF- $\beta$ stimulation in lung fibroblasts.

suppress p38 MAPK phosphorylation, which was increased by TGF- $\beta$ stimulation of LFs: the levels of p38 MAPK phosphorylation in LFs treated with $25 \mathrm{pg} \cdot \mathrm{mL}^{-1} \mathrm{TBH}$ was nearly identical (not significant; $P>0.05$ ) to that observed in TGF$\beta$-stimulated cells (Figure 6). On the other hand, treatment of cells with TBH at $15 \mathrm{pg} \cdot \mathrm{mL}^{-1}$ or more caused significant suppression of phosphorylation of both JNK and ERK1/2, which were increased by TGF- $\beta$ stimulation (Figure 6).

\section{Discussion}

The present results clearly show that $\mathrm{TBH}$ at more than $15 \mathrm{pg} \cdot \mathrm{mL}^{-1}$, which is extremely low compared with therapeutic blood levels, ${ }^{25}$ could suppress the production of both MMP-1 and MMP-2 from LFs, with no detectable effect on the production of TIMP-1 and TIMP-2. In addition, this inhibitory action of TBH on MMP-1 and MMP-2 production is due, in part, to its suppressive effect on MMP mRNA expression,
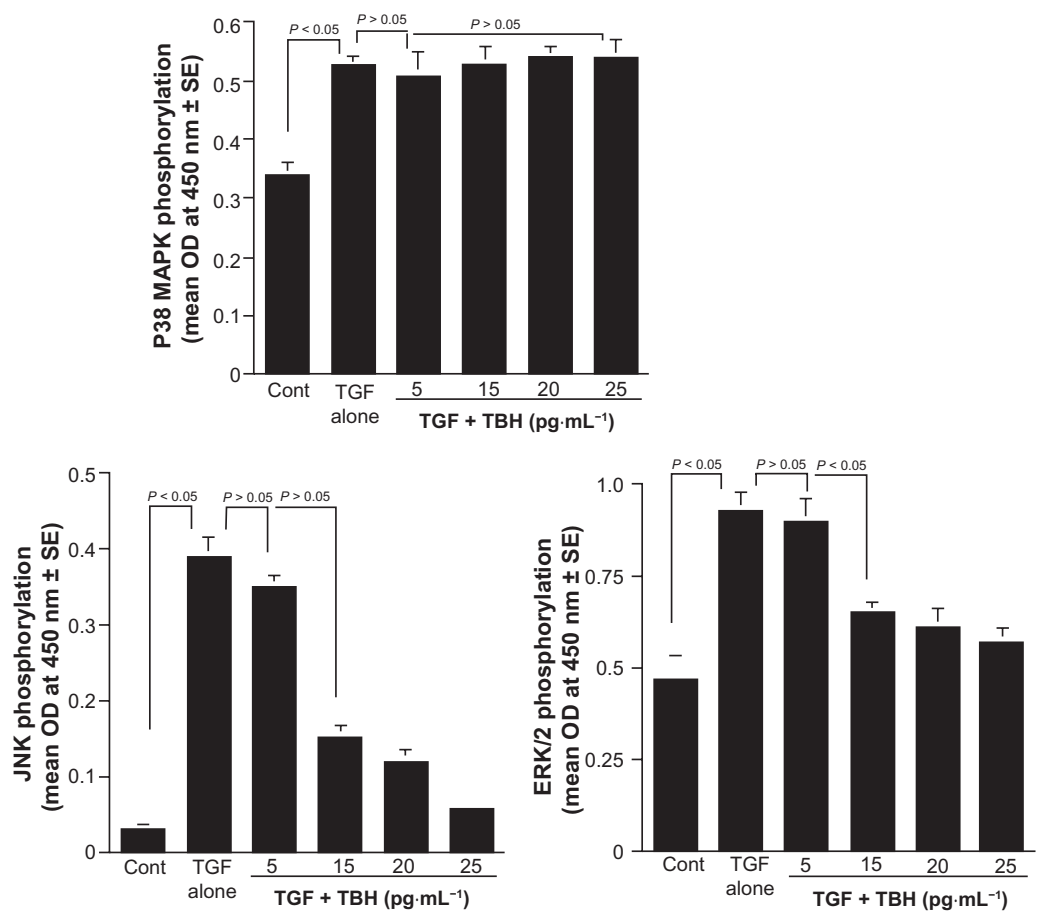

Figure 6 Influence of tiotropium bromide hydrate (TBH) on signaling protein phosphorylation in lung fibroblasts after TGF- $\beta$ stimulation. 
through the inhibition of both Smads signaling pathways and signaling protein phosphorylation, especially JNK and ERK1/2, induced by TGF- $\beta$ stimulation.

COPD is characterized by the presence of a partially reversible airflow obstruction. This pathology is also associated with an airway inflammation process characterized by intense accumulation of inflammatory cells, such as macrophages and neutrophils, in airways and lung. ${ }^{3,4}$ It is believed that the development of emphysema, which is the most important histological finding of COPD, reflects a relative excess of proteases that degrade the connective tissues of the lung and a relative paucity of anti-proteolytic defenses. ${ }^{26}$ This concept is often referred to as the proteaseantiprotease imbalance hypothesis and involves mainly serine proteases, including MMPs. ${ }^{26}$ Immunohistochemical analysis of collagenase and gelatinase expression in COPD, MMP-1, $-2,-8$, and -9 were found to be upregulated..$^{2,8}$ In a study combining RT-PCR, ELISA, immunohistochemistry, and collagen degradation assay, to analyse MMP-1, -9, and -12, increased MMP-1 expression was observed in patients with COPD. ${ }^{27}$ It is also reported that sputum from patients with COPD showed an increased gelatinolytic activity, which linked to MMP-2. ${ }^{28}$ Furthermore, it is reported that the activated forms of MMP-9 and prometalloproteinase-2 (proMMP-2) were found in the sputum of $85 \%$ and $25 \%$ of COPD patients, respectively. ${ }^{29}$ From these reports, it is possible that the attenuating effect of TBH on MMP-1 and MMP-2 production from LFs induced by TGF- $\beta$ stimulation, may underlie the therapeutic mode of action of the agent on COPD. The extracellular activity of MMPs is regulated by TIMPs that form a 1:1 complex with MMPs. ${ }^{26}$ The present results clearly show that TBH could not inhibit TIMP-1 and TIMP-2 production from LFs after TGF- $\beta$ stimulation, suggesting that MMP-1 and MMP-2, secreted in small amounts from LFs during TBH treatment, are inactivated by TIMPs, resulting in modification of clinical symptoms derived from ECM remodeling and accumulation of inflammatory cells in COPD.

TGF- $\beta$ is a pleiotropic cytokine that functions both during development and in the adult, by affecting cell differentiation, growth, apoptosis, and immune responses. ${ }^{13,14}$ Upon TGF- $\beta$ stimulation, the type I and type II receptors form a stable complex, in which the constitutive serine-threonine kinase of the type II receptor activates the type I receptor. ${ }^{30}$ The activated type I receptor phosphorylates Smad-2 and Smad-3 at C-terminal serines. ${ }^{30,31}$ These receptor-activated Smads then form trimers with Smad-4 that migrate to the nucleus, where they associate with sequence-specific transcription factors, such as AP-1, at regulatory sequence of target genes. ${ }^{30,33}$ There are also other pathways that have been implicated in TGF- $\beta$ signaling: tyrosine phosphorylation of both type I and type II receptors can induce activation of the p38 MAPK pathway, as well as the ERK and JNK MAPK pathways. ${ }^{30,33}$ We then examined the possible mechanisms by which TBH could inhibit MMP-1 and MMP-2 production from LFs in response to TGF- $\beta$ stimulation. The data clearly showed that pre-treatment of LFs with TBH decreased Smad-2 and Smad-4 levels in the nucleus, which are increased by TGF- $\beta$ stimulation in LFs. It is also observed that TBH could suppress phosphorylation of JNK and ERK1/2, but not p38 MAPK, induced by TGF- $\beta$ stimulation, suggesting that TBH inhibits the activation of signal transducers and transcriptional modulators, especially Smad-2 and Smad-4 pathways, and JNK and ERK1/2 pathways. This also resulted in the suppression of MMP-1 and MMP-2 mRNA expression in LFs by TGF- $\beta$ stimulation, which is responsible for inhibition of MMP-1 and MMP-2 production at protein levels. On the other hand, TGF- $\beta$ stimulation has been reported to increase the levels of intracellular $\mathrm{Ca}^{2+}$, which is essential for TGF- $\beta$ receptor phosphorylation. ${ }^{14,31}$ Solifenacin succinate, a newly developed muscarinic receptor antagonist, could inhibit carbachol-induced intracellular $\mathrm{Ca}^{2+}$ mobilization in guinea pig smooth muscle cells and murine submandibular gland cells in vitro. ${ }^{34}$ Solifenacin succinate and the other antimuscarinic drugs, such as darifenacin and oxybutynin chloride, which have higher affinity for muscarinic $\mathrm{M}_{3}$ receptor, are also reported to inhibit an increase in intracellular $\mathrm{Ca}^{2+}$ levels in rat salivary gland cells induced by carbachol stimulation. ${ }^{35}$ Furthermore, otilonium bromide, a muscarinic receptor antagonist, could inhibit increases in intracellular calcium levels in cells from rat colon by blocking L-type calcium channel. ${ }^{36}$ Judging from these reports, there is another possibility that TBH blocks an increase in $\mathrm{Ca}^{2+}$ in cytosole and results in inhibition of MMP-1 and MMP-2 production after TGF- $\beta$ stimulation through the suppression of Smad signaling pathways.

In addition to MMP-1 and MMP-2, MMP-9 and MMP-12 have been the focus of interest in several studies. An increase in MMP-9 activity in the lung parenchyma of patients with emphysema is reported. ${ }^{37}$ MMP-9 and the MMP-9/TIMP-1 ratio are also reported to be increased in induced sputum from patients with COPD. ${ }^{28}$ Alveolar macrophages from patients with COPD express more MMP-9 than those from healthy volunteers and the ability of macrophages to produce MMP-9 is further increased in response to inflammatory stimulation. ${ }^{5}$ 
MMP-12 is able to degrade elastine, which is distributed widely throughout the lungs, and is responsible for the development of emphysema in COPD. ${ }^{26}$ Immunocytochemical analysis of BAL and bronchial biopsy samples from COPD patients revealed the presence of much higher numbers of MMP-12-expressing macrophages, as compared with those from normal subjects. ${ }^{26}$ Therefore, to further elucidate the therapeutic mechanisms of TBH on COPD via suppression of MMP production, it is necessary to examine whether TBH could also suppress the production of MMP-9 and MMP-12 by using macrophages and other inflammatory cells such as neutrophils.

In conclusion, $\mathrm{TBH}$ exerts suppressive effects on MMP production from LFs, through interference ofTGF- $\beta$-mediated signaling pathways and results in favorable modification of the clinical status of COPD.

\section{Acknowledgment}

The authors and thank Nippon Boehringer Ingelhein Co. Ltd. (Tokyo, Japan) for the kind donation of pure powder of TBH.

\section{Disclosure}

The authors report no conflicts of interest in this work.

\section{References}

1. Groneburg DA, Chung KF, Baer E. Models of chronic obstructive pulmonary disease. Respir Res. 2004;5:18-34.

2. Lowrey GE, Henderson N, Blakey JD, Corne JM, Johnson SR. MMP-9 protein level does not reflect overall MMP activity in the airways of patients with COPD. Respir Med. 2008;102:845-851.

3. Hamid Q, Cosio M, Lim S. Inflammation and remodeling in chronic obstructive disease. J Allergy Clin Immunol. 2004;114:1479-1481.

4. Jeffery PK. Remodeling and inflammation of bronchus in asthma and chronic obstructive pulmonary disease. Proc Am Thorac Soc. 2004;1: 176-183.

5. Elkington PTG, Friedland JS. Matrix metalloproteinases in destructive pulmonary pathology. Thorax. 2006;61:259-266.

6. Birkedal-Hansen H. Proteolytic remodeling of extracellular matrix. Curr Opinion Cell Biol. 1995; 7:728-735.

7. Shapiro SD. The macrophage in chronic obstructive pulmonary disease. Am J Respi Crit Care Med. 1999;160(Suppl 2):S29-S32.

8. Baraldo S, Bazzan E, Zanin ME, et al. Matrix metalloproteinase-2 protein in lung periphery is related to COPD progression. Chest. 2007;132: 1733-1740.

9. Kang MJ, Oh YM, Lee JC, Bae JS, Kim KT, Lee KO. Lung matrix metalloproteinase-9 correlates with cigarette smoking and obstruction of airflow. J Korean Med Sci. 2003;18:821-827.

10. Stone PJ, Gottlieb DJ, O'Connor GT, et al. Elastine and collagen degradation products in urine of smokers with and without chronic obstructive pulmonary disease. Am J Respir Crit Care Med. 1995;151: 952-959.

11. Gottlieb DJ, Stone PJ, Sparrow D, et al. Urinary desmosine excretion in smokers with and without rapid decline of lung function: the normative aging study. Am J Respir Crit Care Med. 1996;154:1290-1295.

12. Asano K, Shikama Y, Shibuya Y, et al. Suppressive activity of tiotropium bromide on matrix metalloproteinase production from lung fibroblasts in vitro. Int J COPD. 2008;3:781-790.
13. Bommireddy R, Ormsby I, Yin M, Boivin GP, Babcock GF, Doetschman T. TGF $\beta 1$ inhibits $\mathrm{Ca}^{2+}$-calcineurin-mediated activation in thymocytes. J Immunol. 2003;170:3645-3652.

14. Gooch JL, Gorin Y, Zhang BX, Abboud HE. Involvement of calcineurin in transforming growth factor- $\beta$-mediated regulation of extracellular matrix accumulation. J Biol Chem. 2004;279:15561-15570.

15. Takizawa H, Tanaka M, Takami K, et al. Increased expression of transforming growth factor- $\beta 1$ in small airway epithelium from tobacco smokers and patients with chronic obstructive pulmonary disease (COPD). Am J Respir Crit Care Med. 2001;163:1476-1483.

16. Diemen CC, Postma DS, Vonk JM, Bruinenberg M, Nolte IM, Boezen HM. Decorin and TGF- $\beta 1$ polymorphisms and development of COPD in a general population. Respir Res. 2006;7:89-97.

17. Konigshoff M, Kneidinger N, Eickelberg O. TGF- $\beta$ signaling in COPD: deciphering genetic and cellular susceptibility for future therapeutic regimens. Swiss Med Wkly. 2009;139:554-563.

18. Jeffery PK. Remodeling and inflammation of bronchi in asthma and chronic obstructive pulmonary disease. Proc Am Thorac Soc. 2004;1: 176-183.

19. Haag S, Matthiesen S, Juergens UR, Racke K. Muscarinic receptors mediates stimulation of collagen synthesis in human lung fibroblasts. Eur Respir J. 2008;32:555-562.

20. Rodrigo GJ, Nannini LJ. Tiotropium for the treatment of stable chronic obstructive pulmonary disease: a systemic review with meta-analysis. Pulm Pharmacol Ther. 2007;20:495-502.

21. Hamid Q, Cosio M, Lim S. Inflammation and remodeling in chronic obstructive pulmonary disease. J Allergy Clin Immunol. 2004;114: 1479-1481.

22. Gosens R, Bos IS, Zaagsma J, et al. Protective effects of tiotropium bromide in the progression of airway smooth muscle remodeling. Am J Respir Crit Care Med. 2005;171:1096-1102.

23. Jordana M, Schulman J, McSharry C, et al. Heterogeneous proliferative characteristics of human adult lung fibroblast lines and clonally derived fibroblasts from control and fibrotic tissue. Am Rev Respir Dis. 1987; 137:579-584.

24. Shoji N, Asano K, Furuta A, Hirano K, Suzaki H. Effect of histamine $\mathrm{H}_{1}$ receptor antagonists on TARC/CCL17 and MDC/CCL22 production from $\mathrm{CD} 14^{+}$cells induced by antigenic stimulation. Int Arch Allergy Immunol. 2010; doi10.1159/000318720.

25. Keam SJ, Keating GM. Tiotropium bromide. A review of its use as maintenance therapy in patients with COPD. Treat Respir Med. 2004;3: $247-268$.

26. Lagente V, Manoury B, Nenan S, Le Quement C, Martin-Chouly C, Boichot E. Role of matrix metalloproteinases in the development of airway inflammation and remodeling. Braz J Med Biol Res. 2005;38: $1521-1530$.

27. Imai K, Dalal SS, Chen ES, et al. Human collagenase (matrix metalloproteinase-1) expression in the lung of patients with emphysema. Am J Respir Crit Care Med. 2001;163:786-791.

28. Cataldo D, Munaut C, Noel A, et al. MM-2- and MMP-9-linked gelatinolytic activity in the sputum from patients with asthma and chronic obstructive pulmonary disease. Int Arch Allergy Immunol. 2000;123: 259-267.

29. Demedts IK, Brusselle GG, Bracke KR, Vermaelen KY, Pauwels RA. Matrix metalloproteinases in asthma and COPD. Cur Opin Pharmacol. 2005;5:257-263.

30. Kang JS, Liu C, Derynck R. New regulatory mechanisms of TGF-beta receptor function. Trend Cell Biol. 2009;19:385-394.

31. McGowan TA, Madesh M, Zhu Y, et al. TGF- $\beta$-induced $\mathrm{Ca}^{2+}$ influx involves the type III IP3 receptor and regulates actin cytoskeleton. Am J Physiol Renal Physiol. 2002;282:F910-F920.

32. Liu IM, Schilling SH, Knouse KA, Choy L, Derynck R, Wang XF. TGF $\beta$ stimulated Smad1/5 phosphorylation requires the ALK5 L45 loop and mediates the pro-migratory TGF $\beta$ switch. EMBO J. 2009;28:88-98.

33. Moustakas A, Heldin CH. Non-Smad TGF- $\beta$ signals. J Cell Sci. 2005 ; 118:3573-3584. 
34. Ikeda K, Kobayashi S, Suzuki M, et al. M3 receptor antagonism by the novel antimuscarinic agent solifenacin in the urinary bladder and salivary gland. Naunyn Schiedebergs Arch Pharmacol. 2002;366:97-103.

35. Ohtake A, Ukai M, Hatanaka T, et al. In vitro and in vivo tissue selectivity profile of solifenacin succinate (YM905) for urinary bladder over salivary gland in rats. Eur J Pharmacol. 2004;492:243-250.
36. Martin MT, Hove-Madsen L, Jimenz M. Otilonium bromide inhibits muscle contractions via L-type calcium channels in the rat colon. Neurogastroenteol Motif. 2004;16:175-183.

37. OhnishiK, Takagi M,KurokawaY, etal. Matrix metalloproteinase-mediated extracellular matrix protein degradation in human pulmonary emphysema. Lab Invest. 1998;78:1077-1087.

\section{Publish your work in this journal}

The International Journal of COPD is an international, peer-reviewed journal of therapeutics and pharmacology focusing on concise rapid reporting of clinical studies and reviews in COPD. Special focus is given to the pathophysiological processes underlying the disease, intervention programs, patient focused education, and self management protocols.
Dovepress

This journal is indexed on PubMed Central, MedLine and CAS. The manuscript management system is completely online and includes a very quick and fair peer-review system, which is all easy to use. Visit http://www.dovepress.com/testimonials.php to read real quotes from published authors.

Submit your manuscript here: http://www.dovepress.com/international-journal-of-copd-journal 